\title{
The developments of anaerobic baffled reactor for wastewater treatment: A review
}

\author{
Rongrong Liu*, Qing Tian and Jihua Chen \\ Department of Environmental Science and Engineering, DongHua University \\ 2999 North Renmin Road, Songjiang district, Shanghai 201620, China. \\ Accepted 30 December, 2009
}

\begin{abstract}
With the increasing deterioration of world water resources, configuring a technical and economic viable wastewater treatment and recycle technology to satisfying the increasing complexity of wastewater and stringent environmental regulation has been a great challenge over the past decades. Developing reliable technologies for wastewater treatment is of urgent importance. In recent years, anaerobic baffled reactor (ABR) treating wastewaters effectively, have received considerable attention in the literature. This paper reviews the development and application, performance and characteristics, modeling of the ABR for wastewater treatment and the combination of $A B R$ with other processes during the last decade. This paper provides a critical review on the ABR for treatment of refractory wastewaters. It was indicated that ABR had become a promising alternative for wastewaters treatment with great further development potential.
\end{abstract}

Key words: Anaerobic baffled reactor, anaerobic process, reactor development, performance, solids retention, full-scale.

\section{INTRODUCTION}

With the improvement of world economic condition, water resources are becoming increasingly deficient and the quality of environment in the world is constantly becoming worse in most regions. Treatment and disposal of wastewater is presently one of the serious environmental problem contributors. Therefore, there is a dire need to develop reliable technologies for wastewater treatment.

Anaerobic process for wastewater treatment has attracted increasing attention. This process has advantages as

${ }^{*}$ Corresponding author. E-mail: rongrongair@163.com. Tel: +86 2167792544 (5). Fax: +86 2167792522.

Abbreviations: ABR, anaerobic baffled reactor; CABR, carrier anaerobic baffled reactor; COD, chemical oxygen demand; CSTR, completely stirred tank reactor; GRABBER, granularbed anaerobic baffled reactor; HMABR, hybrid aerating membrane-anaerobic baffled reactor; HRT, hydraulic retention time; MABR, modified anaerobic baffled reactor, NB, nitrobenzene; PABR, periodic anaerobic baffled reactor; PNP, p-nitrophenol; RTD, residence time distribution; SFABR, splitfeed anaerobic baffled reactor; SRT, solid retention time; TCOD, total chemical oxygen demand; UASBs, anaerobic sludge blanket reactors; VFA, volatile fatty acid. design simplicity, use of non-sophisticated equipment, high treatment efficiency, low excess sludge production and low operating and capital cost (Abdullah et al., 2005; Saktaywin et al., 2005; Sato et al., 2006). The high-rate anaerobic processes could be achieved by separation between the hydraulic retention time (HRT) and the solid retention time (SRT) (Pol et al., 2004). In addition, stringent environmental legislation is giving the impetus to developing anaerobic wastewater treatment processes due to potential economic and environmental benefits they hold over traditional aerobic techniques (Zakkour et al., 2001).

Nowadays, many researches have focused on anaerobic reactors for the treatment of wastewater. As one of the high-rate anaerobic reactors, the $A B R$ was extensively used in treating wastewater. The $A B R$ was initially developed at Stanford University and it can be described as a series of up-flow anaerobic sludge blanket reactors (UASBs). As the name suggests, it consists of a series of vertical baffles to force the wastewater to flow under and over them as it passes from the inlet to the outlet. The wastewater can then come into intimate contact with a large amount of active biomass, while the effluent remains relatively free of biological solids (Wang et al., 
2004; Krishna et al., 2007). The significant advantage of the $A B R$ is its ability to separate acidogenesis and methanogenesis longitudinally down the reactor (Barber and Stuckey, 1999; Plumb et al., 2001; Uyanik et al., 2002a). This can permit different bacterial population to dominate each compartment, acidification predominating in the first compartment section and methanogenesis dominant in the subsequent section (Barber and Stuckey, 1999; Plumb and Stuckey, 2001; Uyanik et al., 2002b).

A review paper on ABR was published in 1999. From then on, despite the ever-increasing number of publiccations on $A B R$ in the last decade, there has never been any attempt to collect all the information in a review. Hence, the main objectives of the paper are to summarize some of the developments and applications of $A B R$ and to provide useful information on their most important features. An overview of several recent studies has been reported in this literature, with the performance and characteristics of ABR described or analyzed and compared. To do so, an extensive list of recent literature has been compiled. Modeling of $A B R$, combination of ABR with other processes are presented and discussed. The review also summarizes the application of $A B R$ on pilot scale, which is important to determine the application of ABR on full scale. Compared with the paper published in 1999, this paper added many valuable literatures and demonstrated a worth review on ABR.

\section{DEVELOPMENT AND APPLICATION OF ABR}

Since the original design of $A B R$ was developed for wastewater treatment, many modifications have been made in reactor design in order to enhance both the efficiency and reliability of the reactor. The treatment efficiency of $A B R$ was closely related to the solids retention capacity. Many researches have been conducted into modifications to the configuration of $A B R$ in order to enhance the solids retention capacity, treat refractory wastewater and reduce capital costs. A summary of the main alterations was well documented in 1999 (Barber and Stuckey, 1999). In this paper, other modifications of ABR would be presented.

In 1993, vertical baffled anaerobic sludge bed as a baffled reactor was used to treat wastewater distillers, the structure is shown in Figure 1A. It combined the function of anaerobic contactor reactor, anaerobic filter and UASB simultaneously (Li et al., 2001).

The latest modification of ABR is periodic anaerobic baffled reactor (PABR) developed in 1998. The structure is shown in Figure 1B. The main advantage of PABR is its random operation: different operation periods were chosen to get optimum treatment efficiency under favorable working conditions according to the influent concentration and quantity (Skiadas and Lyberatos, 1998).

In order to avoid or at least decrease clogging and sludge washout of biomass in attached form, enhance the bacterial activity together with better mixing to ensure high-rate contact between the cells and their substrate (Faisal and Unno, 2001), the carrier anaerobic baffled reactor $(\mathrm{CABR})$ was developed to treat sewage at $28 \pm$ $1^{\circ} \mathrm{C}$. It combines the advantages of ABR with the characteristics of biofilm reactor and is a suitable technology for decentralized domestic sewage treatment for rural areas of China (Feng et al., 2008). The structure is shown in Figure 1C.

A study has focused on basic configuration modification of ABR to obtain improved treatment efficiency. A ninechambered modified anaerobic baffled reactor (MABR) was developed to evaluate its suitability for the treatment of municipal wastewater and to establish the understanding of the relationship between reactor design and operational parameters. A long-term operation (375 d) of MABR indicated that the reactor configuration can be exploited for treatment of dilute wastewaters such as municipal wastewater at lower HRT of $0.25 \mathrm{~d}$. The MABR can be useful as an onsite compact wastewater treatment plant for individual houses or small colonies in Indian climatic conditions (Bodkhe, 2009). The structure is shown in Figure 1D.

The performance of the ABR while treating a variety of wastewaters has been well reviewed in the literature (Barber and Stuckey, 1999). In recent years, application of $A B R$ for treatment of wastewater has received considerable attention. The ABR can be used to treat various wastewaters, in particular, low and high strength wastewater and other refractory wastewaters.

\section{Low strength wastewater}

As shown in Table 1, low strength wastewater was effecttively treated using $A B R$ in the last decade. It was indicated that no substantial change occurred in the population of acid producing bacteria down the length of a reactor while treating low strength wastewater with low mass transfer driving force and low biomass activities. The problem of sludge washout with low HRTs can be counteracted with lower gas production rates. Low HRT can increase hydraulic turbulence and enhance treatment efficiency.

\section{High strength wastewater}

ABR was extensively applied in the treatment of high strength wastewaters. A brief summary of the recent literatures available on high strength treatment is shown in Table 2. In order to enhance biomass settling ability, longer retention times are possible and even necessary for concentrated wastewaters treatment. High substrate concentrations will encourage both fast growing bacteria and gas production. Higher levels of gas production increased sludge bed expansion, but the improved settling 

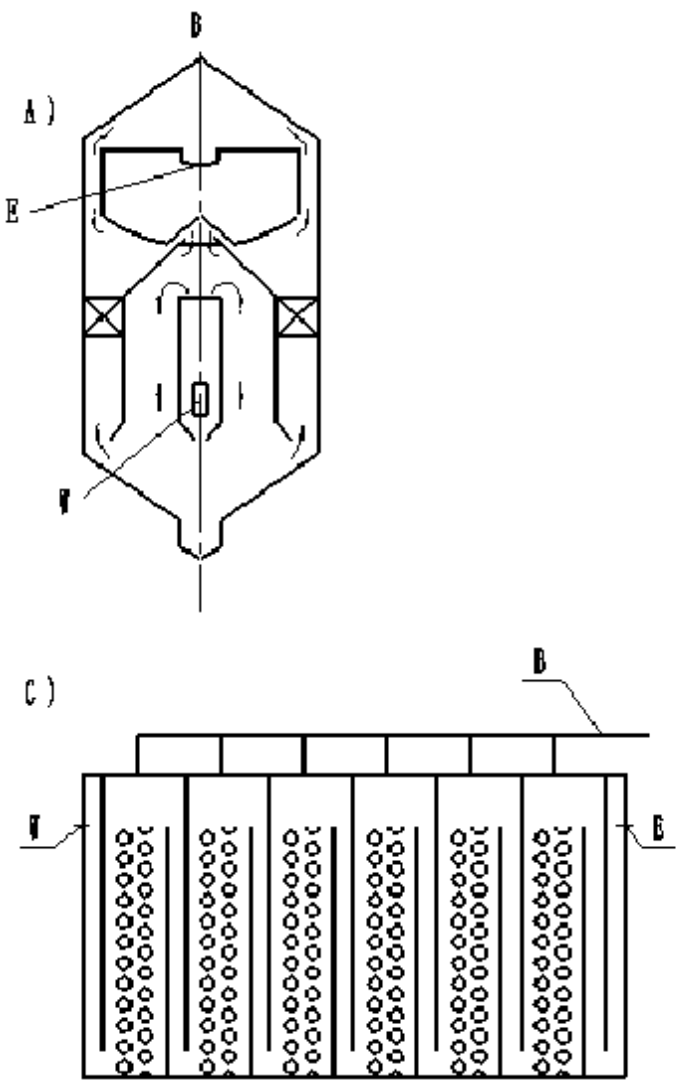

B)
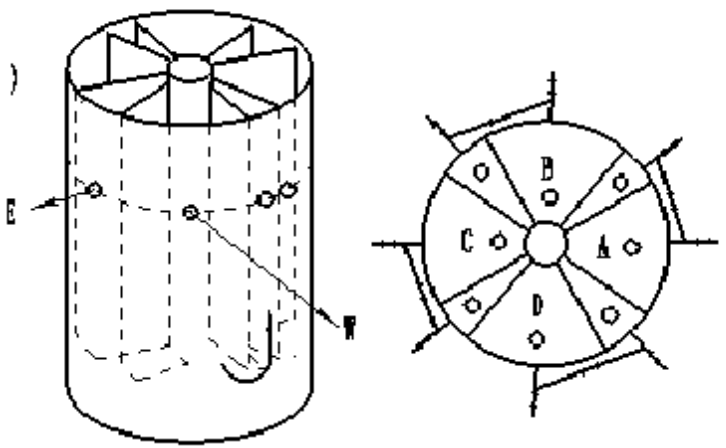

0)

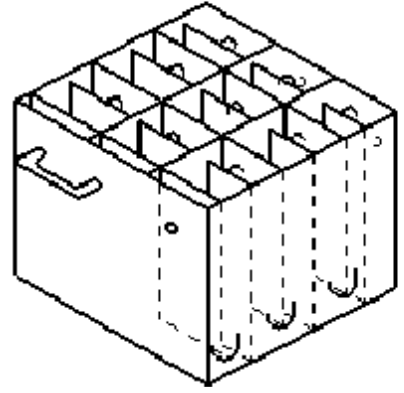

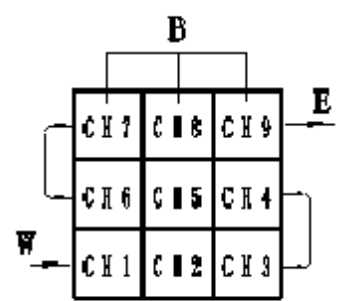

Figure 1. Different types of the ABRB-Biogas. $W=$ wastewater; $E=E$ Effluent.

Table 1. Selected low strength performance data.

\begin{tabular}{|l|c|c|c|c|c|l|}
\hline \multicolumn{1}{|c|}{ Wastewater } & HRT/h & Influent COD (mg/L) & $\begin{array}{c}\text { COD } \\
\text { removal } \\
(\%)\end{array}$ & $\begin{array}{c}\text { OLR } \\
\mathbf{( k g / \mathbf { m } ^ { 3 }} \\
\mathbf{d})\end{array}$ & $\begin{array}{c}\text { Gas } \\
\text { produced } \\
(\mathbf{v} / \mathbf{v} / \mathbf{d})\end{array}$ & \multicolumn{1}{|c|}{ Reference } \\
\hline Synthetic wastewater & 10 & 501 & 90.7 & 1.2 & 0.36 & Gopala Krishna.et al. (2007) \\
Domestic wastewater $^{1}$ & 48 & $305.18 \pm 36.22$ & $74 \pm 5$ & $/$ & $/$ & Feng et al. (2008) \\
Municipal wastewater & 6 & 350 & 86 & 2.62 & 0.34 & Bodkhe (2009) \\
Complex wastewater & 8 & 500 & 88 & 2 & 0.31 & Gopala Krishna et al.(2008) \\
Diluted water & 10 & 500 & 95 & 0.13 & 3.0 & Langenhoff et al. (2000) \\
Domestic wastewater $^{2}$ & 22 & $716 \pm 54.4$ & $72 \pm 3$ & $/$ & $/$ & Foxon et al. (2004) \\
low strength wastewater $^{10}$ & 12 & 550 & 89 & 1.69 & $/$ & Shen et al. (2004) \\
low strength wastewater & 3 & 850 & 90 & 6.9 & $/$ & Shen et al. (2004) \\
\hline
\end{tabular}

$1=$ at $28 \pm 1{ }^{\circ} \mathrm{C} ; 2$ = on pilot scale; others carried out on laboratory scale.

ability of the biomass may have reduced the effects of solids loss caused by the gas. The ABR proved to be an efficient reactor configuration for the treatment of high strength wastewater.

However, the ABR was applied to treat other refractory wastewaters. Due to the compartmentalized configuration which keeps the biomass in the reactor for a long period of time independent of the HRT, the ABR has potential to cultivate special microorganisms and retain them in the reactor to obtain efficient operation, so it will show considerable potential for refractory wastewater treatment. The effect of increasing $p$-nitrophenol (PNP) concentrations on the performance of $A B R$ was investigated through 240 days. The maximum PNP removal efficiency was measured as $99 \%$ at a loading rate of $8.32 \mathrm{~g} / \mathrm{m}^{3}$ day (Kuscu and Sponza, 2005). The effect of the COD/SO ratio on the performance of $A B R$ was explored, maximum COD and sulfate removal were 86 and $97 \%$, respectively 
Table 2. Selected high strength performance data.

\begin{tabular}{|c|c|c|c|c|c|c|}
\hline Wastewater & $\mathrm{HRT} / \mathrm{h}$ & $\begin{array}{c}\text { Influent } \\
\text { COD } \\
(\mathrm{mg} / \mathrm{L}) \\
\end{array}$ & $\begin{array}{c}\text { COD } \\
\text { removal } \\
(\%)\end{array}$ & $\begin{array}{c}\text { OLR } \\
\left(\mathrm{kg} / \mathrm{m}^{3}\right. \\
\mathrm{d})\end{array}$ & $\begin{array}{c}\text { Gas } \\
\text { produced } \\
(\mathbf{v} / \mathbf{v} / \mathbf{d}) \\
\end{array}$ & Ref. \\
\hline Palm oil mill wastewater & 72 & 16000 & 77.3 & 5.33 & 0.33 & Faisal et al. (2001) \\
\hline Whisky distillery wastewater & 96 & 9500 & 96.1 & 2.38 & I & Akunna et al. (2000) \\
\hline Brewery wastewater & 19.23 & 10720 & 93 & 13.38 & / & Baloch et al. (2007) \\
\hline High sulfate wastewater & 240 & 6.6 & 82.71 & 0.66 & 0.29 & Saritpongteeraka et al. (2008) \\
\hline Soybean protein processing wastewater & 39.5 & 10000 & 97 & 6.0 & l & Zhu et al. (2008) \\
\hline Penicillin reduction wastewater & 64 & 8.0 & 65.0 & 2.64 & / & Gong et al. (2006) \\
\hline mixed wastewater & 48 & $<7.6$ & about 50 & $1.5-3.8$ & I & Ji et al. (2007) \\
\hline
\end{tabular}

All these were carried out on laboratory scale.

(Vossoughi et al., 2003). The ABR was also used to treat heavy oil produced wastewater (Ji et al., 2009).

\section{PERFORMANCE AND CHARACTERISTICS OF ABR}

\section{Reactor hydrodynamics}

The hydrodynamics and occurrence of mixing within an ABR strongly influence the extent of contact between substrate and bacteria, thus affecting the whole reactor's treatment efficiency. Previous studies indicated that the ABR has low levels of dead space in comparison with other anaerobic designs. Dead space consists of both hydraulic and biological dead spaces. Hydraulic dead space is a function of the flow rate and the number of compartments in the reactor and the biological dead space is a function of the biomass concentration and activity. An increase in the (hydraulic) dead space was expected with a decrease in HRT while creating less (biological) dead space. However, no direct correlation between hydraulic dead space and HRTs could be drawn.

In the last decade, several studies have focused on residence time distribution (RTD) of $A B R$. Using the calculated dispersion numbers in the $A B R$, it can be concluded that the intermediate was between plug-flow and perfectly mixed (Langenhoff and Stuckey, 2000); It was also indicated that the intermediate was closer to plug flow than completely mixed flow (Krishna et al., 2008; Kong and $\mathrm{Wu}, 2008$ ).

RTD studies were carried out at different temperatures to determine whether the rate of gas production and viscosity affected the hydrodynamics of the ABR. The results indicated that the volume of dead space was relatively constant at the temperatures used, even though less gas was produced at low temperature due to the lower COD removals (Langenhoff and Stuckey, 2000).

By splitting the feed for $A B R$, the flow pattern changed corresponding to a higher degree of mixing within the reactor. The mixing pattern produced by the proper ratio was considered to represent an appropriate intermediate between plug-flow and completely mixed reactors (Sallis and Uyanik, 2003).

Liu et al. (2007) studied hydrodynamic characteristics of a four-compartment PABR. The results showed that the dead space in PABR was similar to that in ABR. The flow patterns within the PABRs were intermediate between plug-flow and perfectly mixed under all conditions tested (Liu et al., 2007).

RTD studies of ABR for treatment of low-strength soluble wastewater were carried out at 8 and 10 h HRTs. The results showed that the volume of dead space decreases with decreasing HRT. This conclusion seemed contradictory to others as this might be due to biological dead space established as the major contributor to overall dead space, the variation of HRT had no significant effect on hydraulic dead space (Krishna et al., 2007).

However, investigations of the hydrodynamics to date have not taken into account other factors, which include biogas mixing effects, viscosity changes due to extracellular polymer production, biomass particle size and the rate of solid particles/biomass within the reactor. Further studies should thus be carried out.

\section{Effluent recycle}

The advantages and disadvantages of effluent recycle have been well summarized in the literature and will not be discussed here. However, with plug flow characteristics, high substrate loading in the front part of the reactor can lead to the accumulation of volatile fatty acid (VFA) and a concomitant decrease in $\mathrm{pH}$, affecting its efficiencies in pollutant removals. High strength wastewater is more likely to expose sensitive bacteria in front compartments to toxic levels of inorganic and organic compounds (Baloch et al., 2007; Yu et al., 2002). To lessen such negative effects, dilution of incoming wastewater can be accomplished by effluent recycle (Kennedy and Barriault, 2005). Additionally, the addition of a recycle stream could also alleviate the problem of low $\mathrm{pH}$ caused by high levels of VFA at the front part of the ABR reactor (Baloch et al., 2007). Also, the organic removal performances have been improved by the 
effluent recycling. When the effluent recycle was applied to treat high sulfate wastewater in $A B R$, the effect was opposite. In effluent recycle, its positive effects as mentioned by other works were not realized; instead it caused a reduction in organic removal and methane yield. Operation at longer HRT and lower effluent recycle ratios could generate the biogas with higher methane content and yield. Effluent recycle also provided an additional alkalinity for a $\mathrm{pH}$ control purpose and toxicity dilution (Saritpongteeraka et al., 2008).

A modified anaerobic baffled bioreactor (MABR) was studied under steady-state conditions for treating palm oil mill wastewater. The stability was achieved by the recycling of 30 times feed flow rate. By recycling the effluent to the influent, the alkalinity in the effluent was recovered (Faisal and Unno, 2001).

Therefore, it was found that the overall effects of recycle are unclear. In practice, the ultimate use of recycle will depend on the type of wastewaters. The effluent recycle will be beneficial if $\mathrm{pH}$ problems are severe. The influent with high levels of toxic material, or high loading rates are preferred. The application of effluent recycling should be cautious and only when absolutely necessary.

\section{Start-up}

Due to slow growth rates of anaerobic microorganisms, especially methanogens, the significant difficulty in ABR operation is the slow start-up procedure, which is crucial to the overall wastewater treatment. Establishment of the most suitable microbial population is the overall objective of start-up of ABR. The start-up of ABR and its affecting factors have been well presented in the literature (Barber and Stuckey, 1999). Hence, the last decade available literature on the start-up of ABR is reviewed in this paper.

The low initial loading rate was recommended for the successful start-up of ABR. A low initial volumetric loading rate was beneficial for the growth of anaerobic active sludge, due to low COD volumetric loading resulting in low production of gas rate and low wastewater up-flow velocity. The reactor usually started-up with a constant HRT coupled to a stepwise increase in substrate concentration or with a constant substrate concentration coupled to a stepwise decrease in HRT. The latter provided greater reactor stability and superior performance than the former.

The performance of a carrier anaerobic baffled reactor (CABR) during start-up was investigated. The success of start-up was indicated by total chemical oxygen demand (TCOD), removal efficiency and the varying $\mathrm{pH}$ curve and/or alkalinity along the on site flow measurement (Feng et al., 2008).

As the above mentioned, when the ABR was applied to treat refractory wastewaters, the reactors achieve successful start-up, respectively: it took 60 days to achieve a start-up for treating PNP-containing waste-water; the reactor achieved prompt start-up while treating $\mathrm{SO}_{4}{ }^{2-}$ containing wastewater; the reactor took 164 days to achieve a successful start-up while treating heavy oil produced water (Kuscu and Sponza, 2005; Vossoughi et al., 2003; Ji et al., 2009).

A modified anaerobic baffled reactor (MABR) was developed to treat municipal wastewater. The reactor needed 90 days for start-up without inoculation, the results showed that the time consumed by the MABR for self-inoculation was favorably comparable (Bodkhe, 2009).

\section{The granulation in ABR}

It was indicated that granulation was not necessary in the ABR for optimal performance, but various studies have demonstrated that the granules could appear in the reactor under favorable conditions.

Because the kinetic selection of filamentous bacteria of the Methanotrix $s p$. under a high (over $1.5 \mathrm{~g} / \mathrm{L}$ ) acetate concentration, a faster biomass granulation was observed in the ABR than in the UASB and hybrid reactors (Hutnlian et al., 1999).

The influence of polymer addition on granule formation within an ABR has been reported. The polymer-amended reactor contained sludge that had a greater density of anaerobic bacteria and larger and denser granules than the control reactor, indicating that polymer addition possibly contributed to the retention of active biomass within the ABR (Uyanik et al., 2002). The addition of granular active carbon seemed to be more effective to promote the formation of anaerobic granules and granulation was achieved in each compartment by day 75 (She et al., 2006).

It was indicated that the split-feed anaerobic baffled reactor (SFABR) configuration promoted the formation of granules and the populations of filamentous bacteria developed in the latter stages of granulation rather than being the initial nuclei for granule formation (Sallis and Uyanik, 2003).

It has been reported that white-grey granules appeared in the first compartment while treating low-strength soluble wastewater or heavy oil produced water in ABR. With time, the size of these granules increased, particularly in the earlier compartments (Krishna et al., 2007; Ji et al., 2009).

It has also been reported that the inoculated granules in the first compartment appeared to be broken up and replaced by non-granular fluffy sludge while treating whisky distillery wastewater with granular-bed anaerobic baffled reactor (GRABBR). The brownish fluffy sludge was produced in the compartments where acidogenesis was the principal process taking place, while dark granular sludge was retained mainly where methanogenesis was the main activity (Akunna and Clark, 2000).

From the above discussion, it was indicated that limited study have been carried out on the granulation theories 
and factors promoting granulation in ABR. Hulshoff et al. (2004) have reviewed different granulation theories and factors promoting granulation in UASB-reactors, which maybe helpful for the investigation of granulation in ABR. Further work on this aspect should be carried out (Pol et al., 2004).

\section{MODELING}

In order to simulate and predict performance of $A B R$, several mathematical models of ABR have been developed, which have been well presented in the literature. A kinetic model of glucose consumption, which was developed based on a batch kinetic experiment, was used for the development of a dynamic model for the prediction of the behaviour of the PABR. The PABR may be operated as a UASBR, an ABR or at an intermediate mode. The key assumption of the model is that the hydraulic behaviour of a PABR is equivalent to that of CSTRs in series as concerning the dissolved matter, whereas the biomass is allowed to be retained in the PABR through a retention factor accounting for precipitation. The model adequately predicted the experimental behaviour of glucose fed PABR and used to examine the behaviour of the PABR as a function of operating conditions, both for constant and varying loading rates. It was shown that for different cases, the reactor should be operated as a UASBR or as an ABR (Skiada et al., 2000).

A modified anaerobic baffled bioreactor (MABR) was studied under steady-state conditions for treating palm oil mill wastewater. A kinetic model for substrate utilization and methane production in anaerobic digestion of complex palm oil mill wastewater in MABR is discussed by assuming to take place in three stages: (1) extracellular hydrolysis of complex wastewater into soluble substrates;

(2) transport of the solubilized substrates into cells and (3) utilization of the soluble substrates for cell growth and product formation. Based on the experimental data, the biokinetic parameters were evaluated, which represented the behavior of reactor very well (Faisal and Unno, 2001).

Despite the fact that the mathematical model proposed for design purposes was found to be suitable though some deviations between experimental and theoretical data were observed, there was an urgent need to generate models for larger scale reactors and to model reactor behaviour when hydrolysis is at the rate-limiting step. The improvement of the model, without it becoming too complicated and impracticable for practical applications, is a challenge to be confronted in future researches.

\section{THE COMBINATION OF ABR WITH OTHER PROCESSES}

Although ABR has been widely employed, the high effluent quality is still difficult to meet the increased wastewater discharge standards. To obtain better water quality, the combinations of the anaerobic and aerobic processes, such as: ABR-aerobic biofilm reactor (Bodik et al., 2003) and anaerobic-aerobic stage of a modified ABR (Barber and Stuckey, 2000) among others were researched. Because of system complex, large footprint, high operating costs as well as the requirement of extra circumfluence, a novel hybrid aerating membrane-anaerobic baffled reactor (HMABR) was applied (Hu et al., 2009).

A membrane coupled anaerobic baffled reactor (MABR) was applied for on-site sanitation in low-income areas, which produced the twin benefits of a pathogenfree effluent that is rich in biological nutrients (Pillay et al., 2008).

Sequential ABR/completely stirred tank reactor (CSTR) system was used to treat synthetic wastewater containing PNP and nitrobenzene (NB). The overall COD and PNP removal efficiencies of ABR/CSTR sequential reactor system were up to $94 \%$ until $2.1 \mathrm{~kg} \mathrm{COD} / \mathrm{m}^{3}$ day of OLR and the removal efficiencies of NB were near $100 \%$ for all NB concentrations in ABR reactor (Kuscu and Sponza, 2006; 2009).

\section{PILOT-SCALE EXPERIMENT}

A previous project studied the performance of a $3000 \mathrm{~L}$ pilot ABR treating domestic wastewater at a council-run wastewater treatment facility (Foxon et al., 2004; Foxon et al., 2005). The ABR has the potential as a primary sanitation pre-treatment option in low-income communities: it has been shown to remove between 58 and $72 \%$ of COD entering in the feed and to reduce total suspended solids and pathogen indicator organisms in the wastewater. The design limits of the technology have not been fully investigated for this application. The performance data of a full-scale plant has been presented in the literature.

\section{CONCLUSIONS}

The state-of-the-art in the field of ABR for treatment of wastewater is reviewed in this paper, based on a substantial number of relevant references published recently; it can be concluded that the ABR could be applied to treat various wastewaters with satisfactory results if integrated with proper technology. As a high-rate anaerobic reactor, ABR has considerable potential for wastewater treatment. There are abundant literatures concerning reactor development and application, performance and characteristics, modeling, combination of $\mathrm{ABR}$ with other processes. It was indicated that combinations of $A B R$ and other processes had potential to treat refractory wastewaters. Limited studies have been carried out on the application of $A B R$ on pilot and full scale. 
It is suggested that future researches work on the following aspects: how to solve excessive acidification problem of $A B R$ under high $C O D$ volumetric loadings; the formation and metabolizing mechanism of intermediate products, integration of $A B R$ with other processes for treatment of refractory wastewater ingredients and the confirmation of the parameters of the processes applied in full-scale practices.

\section{ACKNOWLEDGEMENTS}

This work was supported by the Innovation Foundation of Donghua University for Ph.D. candidates (BC200828) and the Key Subject Construction Item of Shanghai City (B604).

\section{REFERENCES}

Akunna JC, Clark M (2000). Performance of a granular-bed anaerobic baffled reactor (GRABBR) treating whisky distillery wastewater. Bioresour. Technol. 74: 257-261.

Baloch MI, Akunna JC, Collier PJ (2007). The performance of a phase separated granular bed bioreactor treating brewery wastewater. Bioresour. Technol. 98: 1849-1855.

Barber WP, Stuckey DC (1999). The use of the anaerobic baffled reactor $(A B R)$ for wastewater treatment: a review. Water Res. 33: 1559-1578.

Barber WP, Stuckey DC (2000). Nitrogen removal in a modified anaerobic baffled reactor (ABR): 2, nitrification. Water Res. 34: 24232432.

Bodik I, Kratochvil K, Gaspirkova E, Hutnan M (2003). Nitrogen removal in an anaerobic baffled filter reactor with aerobic post-treatment. Bioresour. Technol. 86: 79-82.

Bodkhe SY (2009). A modified anaerobic baffled reactor for municipal wastewater treatment. J. Environ. Manage. 90: 2488-2493.

Faisal M, Unno H (2001). Kinetic analysis of palm oil mill wastewater treatment by a modified anaerobic baffled reactor. Biochem. Eng. J. 9: 25-31.

Feng HJ, Hua Lf, Mahmood Q, Quu CD, Fang CR, Shen DS (2008). Anaerobic domestic wastewater treatment with bamboo carrier anaerobic baffled reactor. Int. Biodeter. Biodegr. 62: 232-238.

Foxon KM, Pillay S, Lalbahadur T, Rodda N, Holder F, Buckley CA (2004). The anaerobic baffled reactor (ABR): An appropriate technology for on-site sanitation. Water SA. 30: 592-597.

Foxon KM, Buckley CA, Brouckaert CJ, Dama P, Mtembu Z, Rodda N, Smith MT, Pillay S, Arjun N, Lalbahadur T, Bux F (2005). Evaluation of the Anaerobic Baffled Reactor for Dense Peri-Urban Settlements. WRC Report No. 1248/1/06, pp. 1-224.

Gong YK, Xiang HQ, Mu L (2006). Study on performance of anaerobic baffled reactor for treating wastewater from penicillin production. Modern Chem. Ind. 26 (Supplement): 172-175 (Chinese).

Krishna GVT, Kumar P, Kumar P (2007). Treatment of low-strength soluble wastewater using an anaerobic baffled reactor (ABR). J. Environ. Manage. 90: 1-11.

Krishna GVT, Kumar P, Kumar P (2008). Treatment of low strength complex wastewater using an anaerobic baffled reactor (ABR). Bioresour. Technol. 99: 8193-8200.

Hulshoff Pol LW, Lopes CIS, Lettinga G, Lens LNP (2004). Anaerobic sludge granulation. Water Res. 38: 1376-1389.

Hu SW, Yang FL, Liu ST, Yu LQ (2009). The development of a novel hybrid aerating membrane-anaerobic baffled reactor for the simultaneous nitrogen and organic carbon removal from wastewater. Water Res. 43: 381-388.

HutnÏan M, Drtil M, MrafkovaÂ L, Derco J, Buday J (1999). Comparison of startup and anaerobic wastewater treatment in UASB, hybrid and baffled reactor. Bioproc. Eng. 21: 439-445.
Kennedy K, Barriault M (2005). Effect of recycle on treatment of aircraft de-icing fluid in an anaerobic baffled reactor. Water SA 31: 377-384.

Kong HL, Wu HF (2008). Pretreatment of textile dyeing wastewater using an anoxic baffled reactor. Bioresour. Technol. 99: 7886-7891.

Kuscu ÖS, Sponza DT (2005). Performance of anaerobic baffled reactor (ABR) treating synthetic wastewater containing $p$-nitrophenol. Enzyme Microb. Technol. 36: 888-895.

Kuscu ÖS, Sponza DT (2006). Treatment efficiencies of a sequential anaerobic baffled reactor (ABR)/completely stirred tank reactor (CSTR) system at increasing $p$-nitrophenol and COD loading rates. Process Biochem. 41: 1484-1492.

Kuscu ÖS, Sponza DT (2009). Effects of nitrobenzene concentration and hydraulic retention time on the treatment of nitrobenzene in sequential anaerobic baffled reactor (ABR)/continuously stirred tank reactor (CSTR) system. Bioresour. Technol. 100: 2162-2170.

Ji FY, Wei XJ, Zhang LJ, Han WY (2007). Study on treatment of fine chemical wastewater by anaerobic baffled reactor.China water \& wastewater. 23: 19-23 (Chinese).

Ji GD, Sun TH, Ni JR, Tong JJ (2009). Anaerobic baffled reactor (ABR) for treating heavy oil produced water with high concentrations of salt and poor nutrient. Bioresour. Technol. 100: 1108-1114.

Langenhoff AAM, Stuckey DC (2000). Treatment of dilute wastewater using an anaerobic baffled reactor: effect of low temperature. Water Res. 34: 3867-3875.

Abdullah LG, Idris A, Ahmadun FR, Baharin BS, Emby F, Megat MNMJ, Nour AH (2005). A kinetic study of a membrane anaerobic reactor (MAR) for treatment of sewage sludge. Desalination 183: 439-445.

Li G, OuYang F, Yang LZ (2001). Study on the performance of ABR reactor: review and summary. China Biogas. 19: 9-14 (Chinese).

Liu XL, Ren NQ, Wan CL (2007). Hydrodynamic characteristics of a four-compartment periodic anaerobic baffled reactor. J. Environ. Sci. 19: 1159-1165.

Pillay S, Foxon KM, Buckley CA (2008). An anaerobic baffled reactor/membrane bioreactor $(\mathrm{ABR} / \mathrm{MBR})$ for on-site sanitation in low income areas. Desalination 231: 91-98

Plumb J, Bell J, Stuckey DC (2001). Microbial populations associated with treatment of an industrial dye effluent in an anaerobic baffled reactor. Appl. Environ. Microbiol. 67: 3226-3235.

Saktaywin W, Tsuno H, Nagare H, Soyama T, Weerapakkaroon J (2005). Advanced sewage treatment process with excess sludge reduction and phosphorus recovery. Water Res. 39: 902-910.

Sallis PJ, Uyanik S (2003). Granule development in a split-feed anaerobic baffled reactor. Bioresour. Technol. 89: 255-265.

Saritpongteeraka K, Chaiprapat S (2008). Effects of pH adjustment by parawood ash and effluent recycle ratio on the performance of anaerobic baffled reactors treating high sulfate wastewater Bioresour. Technol. 99: 8987-8994.

Sato N, Okubo T, Onodera T, Ohashi A, Harada H (2006). Prospects for a selfsustainable sewage treatment system: a case study on fullscale UASB system in India's Yamuna River Basin. J. Environ. Manage. 80: 198-207.

Shen YL, Sun LZ, Guan W, Ye F (2004). Treatment of low strength wastewater by anaerobic baffled reactor (ABR). Jiangsu Environ. Sci. Technol. 17: 1-5 (Chinese).

She ZL, Zheng XL, Yang BR, Jin CJ, Gao MC (2006). Granule development and performance in sucrose fed anaerobic baffled reactors. J. Biotechnol. 122: 198-208.

Skiadas IV, Lyberatos G (1998). The periodic anaerobic baffled reactor Water Sci. Technol. 38: 401-408.

Skiada IV, Gavala H N, Lyberatos G (2000). Modelling of the periodic anaerobic baffled reactor (PABR) based on the retaining factor concept. Water Res. 34: 3725-3736

Uyanik S, Sallis PJ, Anderson GK (2002). The effect of polymer addition on granulation in an anaerobic baffled reactor (ABR). Part 1: process performance. Water Res. 36: 933-943.

Uyanik S, Sallis PJ, Anderson GK (2002a). The effect of polymer addition on granulation in an anaerobic baffled reactor (ABR). Part 1: process performance. Water Res. 36: 933-943.

Uyanik S, Sallis PJ, Anderson GK (2002b). The effect of polymer addition on granulation in an anaerobic baffled reactor (ABR). Part II: compartmentalization of bacterial populations. Water Res. 36: 944955 
Vossoughi M, Shakeri M, Alemzadeh I (2003). Performance of anaerobic baffled reactor treating synthetic wastewater influenced by decreasing COD/SO 4 ratios. Chem. Eng. Process. 42: 811-816.

Wang JL, Huang YH, Zhao X (2004). Performance and characteristics of an anaerobic baffled reactor. Bioresour. Technol. 93: 205-208.

Yu HQ, Hu ZH, Hong TQ, Gu GW (2002). Performance of an anaerobic filter treating soybean processing wastewater with and without effluent recycle. Process Biochem. 38: 507-513.
Zakkour PD, Gaterell MR, Griffin P, Gochin RJ, Lester JN (2001). Anaerobic treatment of domestic wastewater in temperate climates: treatment plant modelling with economic considerations. Water Res. 35: 4137-4149.

Zhu GF, Li JZ, Wu P, Jin HZ, Wang Z (2008). The performance and phase separated characteristics of an anaerobic baffled reactor treating soybean protein processing wastewater. Bioresour. Technol. 99: 8027-8033.

THE REFERENCES COLOURED IN RED WERE NOT CITED IN THE MAIN WORK. PLEASE EFFECT THIS CORRECTION OR IT WOULD BE DELETED. 